\title{
PULICAT LAKE: A FRAGILE ECOSYSTEM UNDER THREAT
}

\author{
R. SARASWATHY ${ }^{*}$, Pitchai Kasinatha PANDIAN ${ }^{2}$
}

\section{Abstract}

The Pulicat Lake is the second largest brackish water lake after Chilika Lake in India. The average area of the water spread is $461 \mathrm{sq} \mathrm{km}$. During the monsoon Pulicat Lake receives freshwater through three major rivers, namely, the Swarnamukhi, the Kalangi and the Arani .The Pulicat lagoon system, which is a storehouse of rich biological resources, is under great threat because of the anthropogenic influences. The Pulicat Lake ecosystem is degraded by siltation, bar mouth dynamics, shell mining and processing and population pressure due to the resettlement of villagers from Sriharikota Island. It has been determined that the extent of the lake, including its water spread area, is decreasing. Therefore, it is essential to assess the land use / land cover changes taking place in and around Pulicat Lake using remote sensing and GIS. Studies on its sediment characteristics are also vital. The grain size content reveals that most of the sediments contain clay and silt in enormous amounts. This lake has been the prime source of a livelihood through fishing for a large section of the population living in the surrounding villages. It is the most important refuge for water birds in south India. The fishing community who lives in and around Pulicat Lake follows the Padu system for fishing in the lake. In this study, apart from studies on configuration changes and sediment analysis, a study of the flora and fauna of the lake and the socio-economic conditions of the local community were also carried out. Finally, mitigation measures for the sustainable protection of the lake's ecosystem were identified.

\section{Address}

1 Assistant Professor, Department of Civil Engineering, Tagore Engineering College Rathinamangalam, Chennai, Tamil Nadu. PIN: 600127

2 Professor in Civil Engineering and Principal, Karpaga Vinayaga College of Engineering and Technology, Padalam - 603308, Kancheepuram District, Tamil Nadu.

* Corresponding author: sarah.tagore@gmail.com

\section{Key words}

- Pulicat,

- Brackish Water,

- Lake Ecosystem,

- Sediment

- Flora,

- Fauna.

\section{INTRODUCTION}

Pulicat Lake evolved 6000 years ago at the peak of the Holocene sea level rise from the growth of a coastal sand barrier across the eastern side of the captured river plains. It is the second largest brackish water lake and at the same time, it is a very fragile ecosystem in India[1]. It is fed by the Aarani River at the southern tip and the Kalangi River from the northwest. The Buckingham Canal, a navigation channel, passes through the lagoon[2]. On the eastern boundary of this lagoon is Shriharikota Island, which separates the lagoon from the Bay of Bengal. The lagoon is shallow with large areas of mudflats and sandflats. In general, the seawater enters the lagoon through the northern end near Shriharikota Island and flows back into the Bay of Bengal through the southern end. The salinity is greatly affected by rain. There is a sand- 
bar formation at the northern end where the lagoon is separated from the sea, and this has to be removed manually if the rains do not wash it away. The closure of the sand bar (either due to a lack of rain or massive sand deposition) leads to depletion of the fish stock, as the lagoon acts as a nursery for the hatchlings. The Pulicat Lake yields an average sediment accumulation rate of $12.34 \mathrm{~mm}$ yr-1[2] .

The lagoon is a delicate system that requires constant inflow of seawater and gets adversely affected by sand deposition.About 1 lakh $(100,000)$ people living in and around the lake are dependent on this lake for their livelihood. It is considered as a storehouse of rich biological resources. It has been the prime source of a livelihood through fishing for a large section of population living in the surrounding villages.It is also the most important refuge for water birds in southern India. The International Union for the Conservation of Nature and Natural resources (IUCN) declared the Pulicat lagoon as a Ramsar site (an internationally recognized wetland under the Ramsar Convention) of international importance, and the World Wide Fund for Nature declared it to be a protected area[3]. It also has rich flora and fauna, which support active commercial fisheries and a large varied bird population[4].

The fishing community that lives in and around Pulicat Lake follows the Padu system for fishing in the lake[5]. The Padu system, a traditional common property resource institution, has defined fishing access rights in coastal communities throughout southern India and Sri Lanka over many generations. It is practiced in the villages surrounding Pulicat Lake, India's second largest coastal lagoon and an important artisanal fishery. The informal Padu fishing system operating in the Pulicat Lake is a verbal agreement of traditional fishing rights largely dominated by the Pattinaver caste, which is the traditional fishing caste in Tamil Nadu. In Tamil, the term Padu means fishing place and the Padu system is the way in which both fishing spaces (Padus), and fishing equipment are regulated in the lagoon. Shrimp farming on more than 1000 acres on the eastern part of the lagoon has affected the Pulicat bird sanctuary and the livelihood of 30,000 fishermen and 20,000 farmers[6].

The lake is currently the focus of environmental concerns which are attributable to issues such as the pollution of both the sediment and water columns by trace metals and nutrients, increased turbidity (especially during high wind conditions), and shoaling of the shallow peripheral bays and stream mouths. Coastal communities and industries find the coastal waters to be convenient locations for dumping their wastes. Priorities must be established in the possible uses of our finest natural resources. Once destroyed, their repair is difficult if not impossible, and it is always costly. During the last 30 years, the lake has increasingly become a victim of diverse environmental tragedies and is under great threat because of anthropogenic influences including overfishing, habitat fragmentation and pollution from chemical fertilizers, pesticides and a thermal power plant[7].

The coastal zones are also facing intense and sustained anthropogenic pressure from a range of driving forces. Pulicat Lake provides nursery and breeding grounds for many species of coastal-marine fauna, including birds, and also supports commercial fishing. Mangroves flourished in Pulicat until the eighteenth century[8]. After several interventions by humans and natural phenomena, the mangrove vegetation started to diminish. At present, there are only a few patches of mangrove plants left in Pulicat Lake; therefore, suitable measures for conservation and restoration are required to prevent the loss of biodiversity. It has also been found that Pulicat Lake has been shrinking not only in its water area but also simultaneously in its depth [9]. In addition fish that prefer deep water are rapidly dwindling in the lake. As per the prediction of Caratini (1994), Pulicat Lake may totally disappear within another century because of the siltation, degrading mangroves and increase in human population around the lake, etc., [10]
This study is aimed at analyzing the deteriorating environmental status of the lake and suggesting future actions to improve the economic conditions of the local community.

This article discusses the current status of the Pulicat Lake's biodiversity and the ecological crisis faced by the lake due to lake-mouth closure issues, its siltation, the shrinkage of the lake, pollution, overfishing, sediment patterns, the degradation of its flora and fauna, and the destruction of natural habitats in the environment[11]. Furthermore, it focuses on the fishing community, including the socio-economic future of their employement, and recommends the remedial measures to mitigate the problems. A healthier lake needs integrated policy approaches, which involve scientific disciplines that address the complexity of the interaction between the social and natural systems in the coastal and marine environments.

\section{STUDY AREA}

Pulicat Lake is located between the $13^{\circ} 26^{\prime}$ and $13^{\circ} 43^{\prime} \mathrm{N}$ latitude and $80^{\circ} 03^{\prime}$ and $80^{\circ} 18^{\prime} \mathrm{E}$ longitude. The dried parts of the lagoon extend up to $13^{\circ} 60^{\prime} \mathrm{N}$ latitude. Pulicat Lagoon extends over the Ponneri and Gummudipundi taluks of Thiruvallur district in Tamil Nadu and Sulurpet and the Tada taluks(Revenue Division) of Nellore district in Andhra Pradesh(Figure.1). The lake is about $60 \mathrm{~km}$ in length, with a width that varies from $0.2 \mathrm{~km}$ to $17.5 \mathrm{~km}$. The lake is brackish to salty. The salinity values of the lake vary from zero during a monsoon to about $52 \mathrm{ppm}$ during the post and pre-monsoon seasons. The area of the lake varies from $250-450$ sq.km between low tide and high tide. The average depth of the water has decreased from $1.5 \mathrm{~m}$ to about $1 \mathrm{~m}$.

The three major primary inflows which feed the lagoon are the Arani River at the southern tip, the Kalangi River from the northwest, and the Swarnamukhi River at the northern end, in addition to some smaller streams. The tidal inlets that open into the lagoon are Tupillipalem, Rayadoravu and Pulicat. Irakkam, Venadu and several smaller islands are located inside the lake. Sriharikota, the village of Pulicat, Dugarajupatnam and Sullurpeta are the settlement areas located around the lake (https://en.wikipedia.org/wiki/Pulicat Lake).

The seawater enters the lake through the flood tide of the Bay of Bengal by two gateways, namely, Pamanjeri and Vepenjeri. The lake empties its water into the Bay of Bengal, through its mouths with each one on either side of a sand spit. The mouth is located in the southeastern corner of the lake. Due to the closing of the mouth during the summer months, the tidal exchange between the lake and sea becomes affected. This changes the water quality of the lake,especially its salinity, which causes major problems for the biodiversity of the lake[12]

\section{MATERIALS AND METHODS}

For this study on the past and present configurations of the Pulicat Lake, the data for the past two decades has been analyzed using QGIS by comparing the base map and satellite data of the Pulicat Lake and the area of the lake has been ascertained. The base map has been prepared by digitizing the study area from Chennai Toposheet using Quantum GIS. By learning the changes that have occurred in the lake, the rate at which the lake is declining in its size can also be assessed. The sediment pattern of the lake has been studied by taking sediment samples all over the lake and analyzing the grain size of the sediments. The sediment tests were conducted using the pre-monsoon, post-monsoon and summer season data for the year 2015 and compared with the 1972 and 2005 data sets. The socio-economic status of the people who are dependent on the lake was analyzed based 


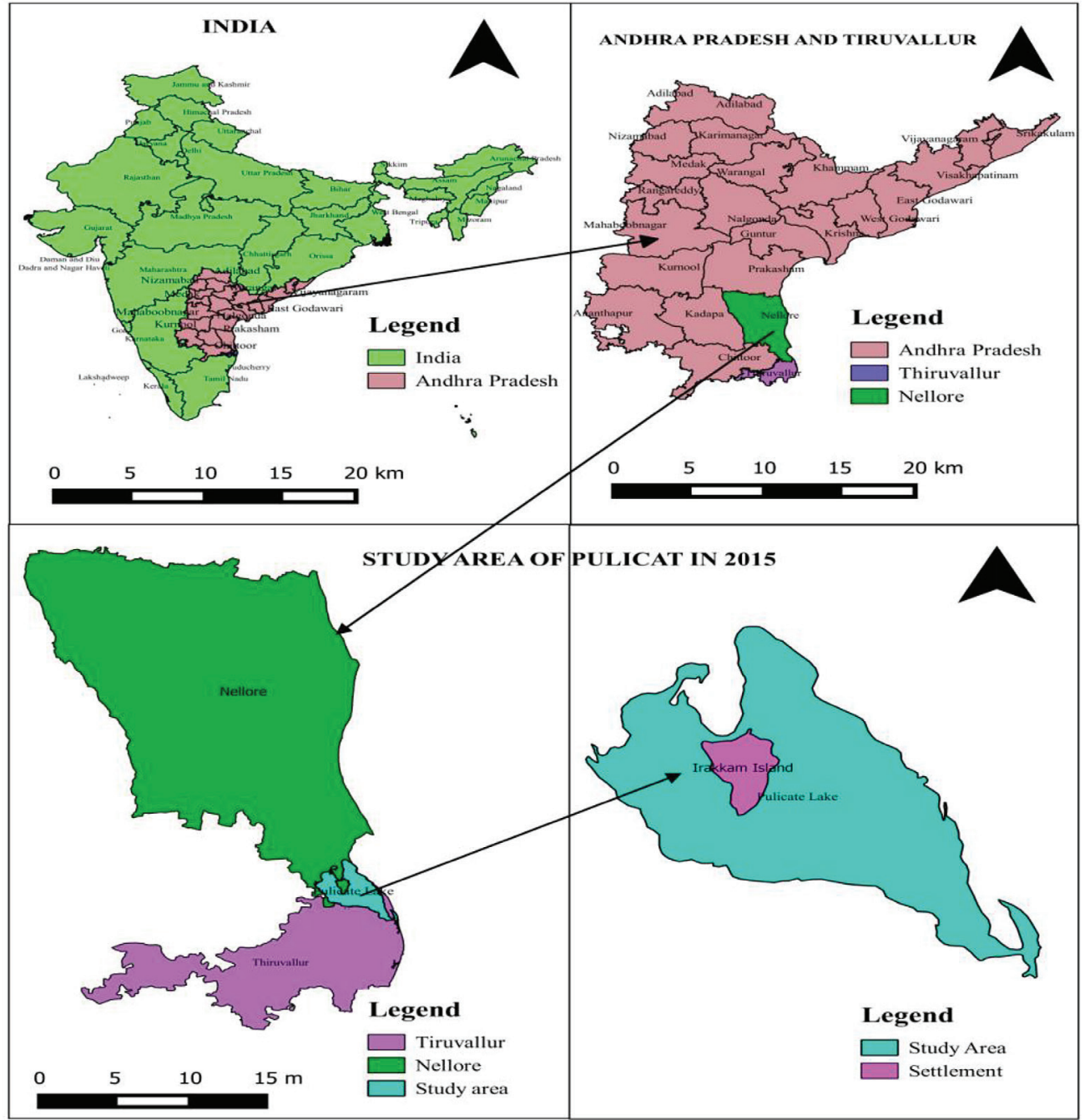

Fig. 1: Map Showing the Study area

on the data collected using a survey questionnaire.The suggestions were proposed based on the findings gathered from various sources like survey results, soil analysis etc.,

\subsection{Sampling Site}

The locations of the sampling points were marked on the base map of the Pulicat Lake with the help of GPS coordinates. The sampling points were randomly selected based on different locations, and numbers were awarded with respect to the nearby station such as $\mathrm{Pu}-$ licat, Sunnambukkulam, Arambakkam and Venadu Island. The GPS coordinates of the sampling points are given in Table.No.1 and the locations of the sample are shown in Figure. No. 2.

After reaching the sampling points by boat, soil sediments were collected from the bottom of the lake by using a scoop and they were packed in the zip lock bags. Sampling point coordinates were saved in the Global Positioning System (GPS) and noted. Simultaneously, the depth of water in the location was also measured. The sediment samples were collected over 26 places starting from Pulicat town covering shore area, center of the lake and near Buckingham Canal, Sunnambukulam, Arambakkam, Veynadu,etc., These samples were collected during pre-monsoon, post-monsoon and summer seasons at the same locations in the year 2015 .

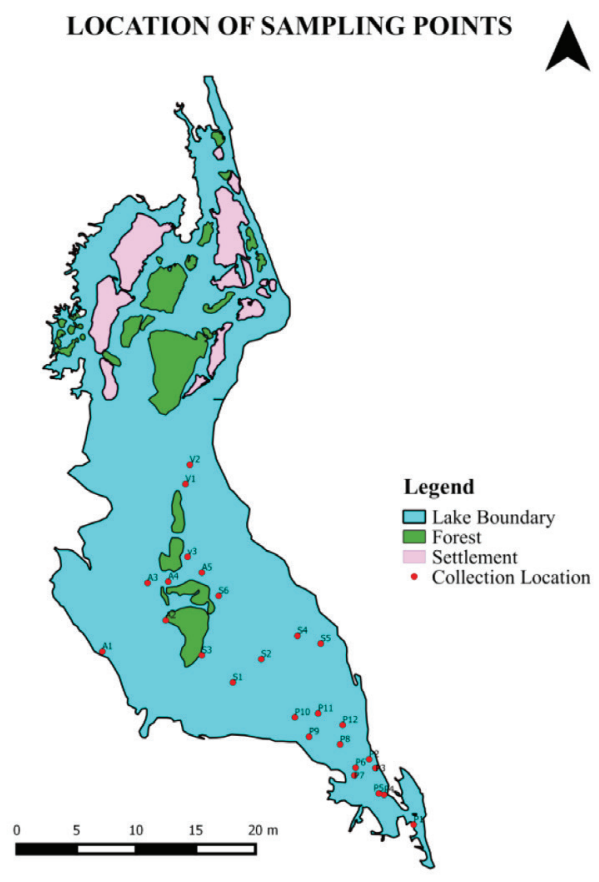

Fig. 2: Location of Sampling Points. 
Table.No.1: GPS Coordinates of Sampling Points

\begin{tabular}{|c|c|c|c|c|}
\hline S.No & Latitude & Longitude & Depth (M) & Location \\
\hline $\mathrm{P} 1$ & $13^{\circ} 25^{\prime} 13.8^{\prime \prime}$ & $80^{\circ} 19^{\prime} 06.9^{\prime \prime}$ & 0.38 & Pulicat jetty \\
\hline $\mathrm{p} 2$ & $13^{\circ} 28^{\prime} 22.6^{\prime \prime}$ & $80^{\circ} 18^{\prime} 15.8^{\prime \prime}$ & Sea & Near tidal inlet \\
\hline P3 & $13^{\circ} 28^{\prime} 13.8^{\prime \prime}$ & $80^{\circ} 18^{\prime} 30.8^{\prime \prime}$ & 1.9 & Lake side near mouth \\
\hline P4 & $13^{\circ} 26^{\prime} 37.1 ”$ & $80^{\circ} 17^{\prime} 46.5^{\prime \prime}$ & 0.53 & Near Buckingham canal inside lake \\
\hline P5 & $13^{\circ} 26^{\prime} 40.3^{\prime \prime}$ & $80^{\circ} 17 ’ 29.6 ”$ & 0.46 & Middle of lake near Avirivakkam \\
\hline P6 & $13^{\circ} 27^{\prime} 54.0^{\prime \prime}$ & $80^{\circ} 16^{\prime} 27.9^{\prime \prime}$ & 1.05 & Middle of lake near Annamalaicherry \\
\hline P7 & $13^{\circ} 27^{\prime} 34.0^{\prime \prime}$ & $80^{\circ} 16^{\prime} 22.8^{\prime \prime}$ & 0.38 & Near Annamalaicherry \\
\hline P8 & $13^{\circ} 28^{\prime} 57.6^{\prime \prime}$ & $80^{\circ} 15^{\prime} 44.2^{\prime \prime}$ & 0.63 & Middle of lake near Virasettitannippandal \\
\hline P9 & $13^{\circ} 29^{\prime} 21.0^{\prime \prime}$ & $80^{\circ} 14^{\prime} 16.9^{\prime \prime}$ & 0.31 & Near Kallur \\
\hline $\mathrm{P} 10$ & $13^{\circ} 30^{\prime} 14.7^{\prime \prime}$ & $80^{\circ} 13^{\prime} 37.7^{\prime \prime}$ & 1.22 & Near Manjakuppam \\
\hline P11 & $13^{\circ} 30^{\prime} 25.2^{\prime \prime}$ & $80^{\circ} 14^{\prime} 40.3^{\prime \prime}$ & 1.3 & Middle of lake near Kallur \\
\hline $\mathrm{P} 12$ & $13^{\circ} 29^{\prime} 52.5^{\prime \prime}$ & $80^{\circ} 15^{\prime} 51.2^{\prime \prime}$ & 0.48 & Near Sriharikota Island \\
\hline A1 & $13^{\circ} 33^{\prime} 16.9^{\prime \prime}$ & $80^{\circ} 04^{\prime} 40.3{ }^{\prime \prime}$ & 0.2 & Arambakkam jetty \\
\hline A2 & $13^{\circ} 34^{\prime} 43.5^{\prime \prime}$ & $80^{\circ} 07^{\prime} 35.8^{\prime \prime}$ & 0.85 & West of Irakkam \\
\hline A3 & $13^{\circ} 36^{\prime} 28.4^{\prime \prime}$ & $80^{\circ} 06^{\prime} 45.9^{\prime \prime}$ & 1.2 & West of Veynadu \\
\hline A4 & $13^{\circ} 36^{\prime} 31.7^{\prime \prime}$ & $80^{\circ} 07^{\prime} 44.2^{\prime \prime}$ & 0.9 & North of Irakkam \\
\hline A5 & $13^{\circ} 36^{\prime} 58.0^{\prime \prime}$ & $80^{\circ} 09^{\prime} 18.5^{\prime \prime}$ & 1.2 & East of Veynadu \\
\hline S1 & $13^{\circ} 31^{\prime} 51.4 ”$ & $80^{\circ} 10^{\prime} 42.9^{\prime \prime}$ & 1 & West of Naduthittu \\
\hline S2 & $13^{\circ} 32^{\prime} 54.7^{\prime \prime}$ & $80^{\circ} 12^{\prime} 02.8^{\prime \prime}$ & 1.5 & East of Naduthittu \\
\hline S3 & $13^{\circ} 33^{\prime} 06.0^{\prime \prime}$ & $80^{\circ} 09^{\prime} 17.0^{\prime \prime}$ & 1.4 & East of Irakkam \\
\hline S4 & $13^{\circ} 34^{\prime} 00.5^{\prime \prime}$ & $80^{\circ} 13^{\prime} 44.4^{\prime \prime}$ & 1.3 & Middle of lake near Kuruvithittu \\
\hline S5 & $13^{\circ} 33^{\prime} 40.7^{\prime \prime}$ & $80^{\circ} 14^{\prime} 49.1^{\prime \prime}$ & 1.55 & Near Pulincherikkuppam \\
\hline S6 & $13^{\circ} 35^{\prime} 52.5^{\prime \prime}$ & $80^{\circ} 10^{\prime} 06.5^{\prime \prime}$ & 1.3 & East of Irakkam \\
\hline V1 & $13^{\circ} 42^{\prime} 38.2^{\prime \prime}$ & $80^{\circ} 07^{\prime} 52.0^{\prime \prime}$ & 0.19 & North of Veynadu \\
\hline $\mathrm{V} 2$ & $13^{\circ} 41^{\prime} 11.5^{\prime \prime}$ & $80^{\circ} 06^{\prime} 44.2^{\prime \prime}$ & 0.20 & Near Veynadu Island \\
\hline V3 & $13^{\circ} 39^{\prime} 22.3^{\prime \prime}$ & $80^{\circ} 05^{\prime} 22.7^{\prime \prime}$ & 0.15 & Veynadu Jetty \\
\hline
\end{tabular}

\subsection{Sample Processing}

The 26 sediment samples collected for the pre-monsoon, Post-Monsson and summer season of the year 2015 were safely transported to the lab and then the analysis was done. In the lab, soil sediments were placed in empty plates and kept in the oven for 24 hours at $110 \mathrm{C}$ to dry the water present in the samples. Then, the dried soil was sieved through the 75 micron sieve. If less than $5 \%$ of soils was retained in the sieve then the hydrometer analysis was done for the sediment samples. The sieve analysis was done for the coarse sand. Along with that, the moisture content of each sample was also found.

\subsubsection{Analysis of Sample}

(i) Moisture content

The moisture content of the soil sample was determined by taking the wet and dry weight of the sample and the percentage of moisture content was calculated by using the formula[13]

$$
\frac{w 2-w 3}{w 3-w 1} \times 100
$$

$\mathrm{W} 1$ - weight of empty tare in grams

W2 - weight of tare + wet sample in grams

W3 - weight of tare + dry sample in grams

\section{(ii) Sieve Analysis}

For the soil samples with coarser sizes like sand, the sieve analysis was done. The sieve analysis was done by taking 500 grams of the dry sample and placing it in the sieve shaker for 10 minutes. The weight of the samples retained in each sieve was measured. The percentage of sand retained in each sieve was noted and it was plotted in the semi-log graph against the sieve size and D10, D30, D50, D60 are observed from the graph.

\section{(iii) Hydrometer Analysis}

The hydrometer analysis was carried out for fine soil such as silt and clay. A total of 500 grams of dried soil was taken and then washed in the 75 micron sieve. If the soil retained in the sample was more than $5 \%$, then the retained soil was taken for sieve analysis. The washed out sand was collected in a container and then the water was drained and the remaining sand was dried in the oven for 24 hours at 
the temperature of 110C. 50 gram of dried soil has been taken and mixed with $50 \mathrm{ml}$ of sodium oxalate solution. The sodium oxalate solution was prepared by adding 0.8 grams of sodium oxalate salt in $100 \mathrm{ml}$ of water. Both the dried soil and solution was then made up to $1000 \mathrm{ml}$ with water in jar, and hydrometer was immersed in the jar. The values were noted for the time interval of 15 and 30 seconds, 1 , $2,4,8,15$, and 30 minutes, $1,2,4,8,16$, and 24 hours. The obtained values were plotted in a semi log graph and the values of D10, D30, D50 and D60 were observed from the graph[14].

\subsection{Studies on Flora and Fauna}

The flora and fauna study was undertaken in the Pulicat Lake Bird Sanctuary and data was collected on pre-monsoon, post-monsoon and summer season of the year 2015 from the sanctuary. In this study various types of fishes and birds recorded in Pulicat Lake were identified through various literatures and also from the biodiversity of India.

\subsection{Socio Economic Study}

The socio economic survey was conducted in the villages in and around Pulicat Lake such as Pulicat town, Arambakkam, Sunnambukulam, Venadu Island and also in other surrounding villages using questionnaires to understand the socio economic status of the local community. The collected data was entered in to Statistical Package for Social Science (SPSS) software and analysis was done. Totally, 891 respondents belonging to 13 villages replied to the questionnaire.

\section{RESULTS AND DISCUSSIONS:}

\subsection{Changes in Configuration of the lake}

The survey of India's topographical maps $66 \mathrm{C} / 1,66 \mathrm{C} / 2,66 \mathrm{C} / 3$, $66 \mathrm{C} / 5$ and $66 \mathrm{C} / 6(2005)$ on 1:50,000 scales were used for the configuration changes coupled with intensive ground truth verifications. The satellite data were geometrically corrected and geo-referenced with the survey of India's topographic maps using ground control points. The satellite data was interpreted based on the visual interpretation keys and changes were identified for the land use and water spread area of the lake using QGIS with reference to a base map of Pulicat from the year 2005.

The analysis shows that major changes were present in the settlement areas. The area of the water body was found to be $691.54 \mathrm{sq}$. $\mathrm{km}$ in 1972(Figure 3), 514.89 sq. $\mathrm{km}$ in 2005(Figure 4) and 354.53 sq. $\mathrm{km}$ in 2015 (Figure 5). The total difference in the water body area between 1972 and 2005 were identified as 176.65 sq. km (Figure 6) and in 1972 and 2015 were identified as 337.03 sq. km(Figure 7). The water spread area present in the lake has been gradually decreased from $74.45 \%$ (2005) to $51.26 \%$ (2015) due to the rapid population growth, siltation and industrial growth in the area.

\subsection{Grain Size of the Sediment Sample}

Totally, 26 locations were selected for collecting samples for the analysis of the grain size of the sediment. These sediment samples were analyzed in the lab for the pre-monsoon season, post-monsoon season and summer season. The grain size analyses of the sediments collected from lake mouth and shore regions of the Bay of Bengal showed medium to coarse sand and sediments on the northern side

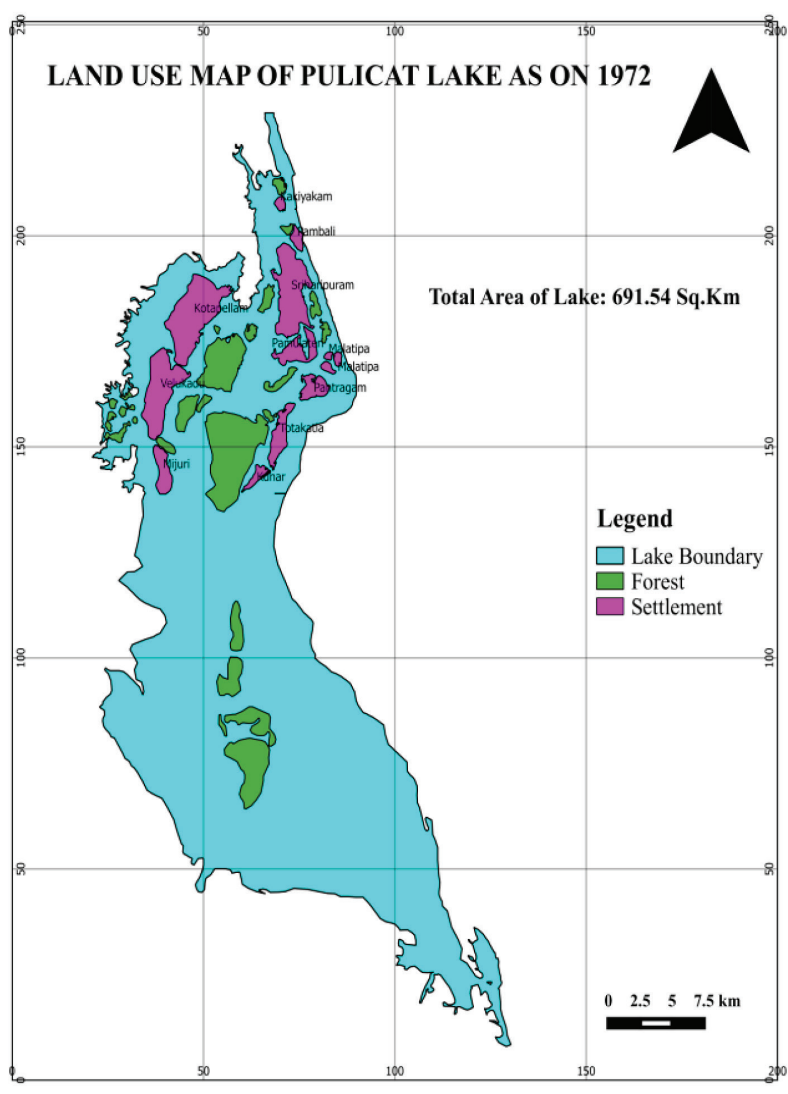

Fig. 3: Land Use Map of Pulicat Lake in 1972

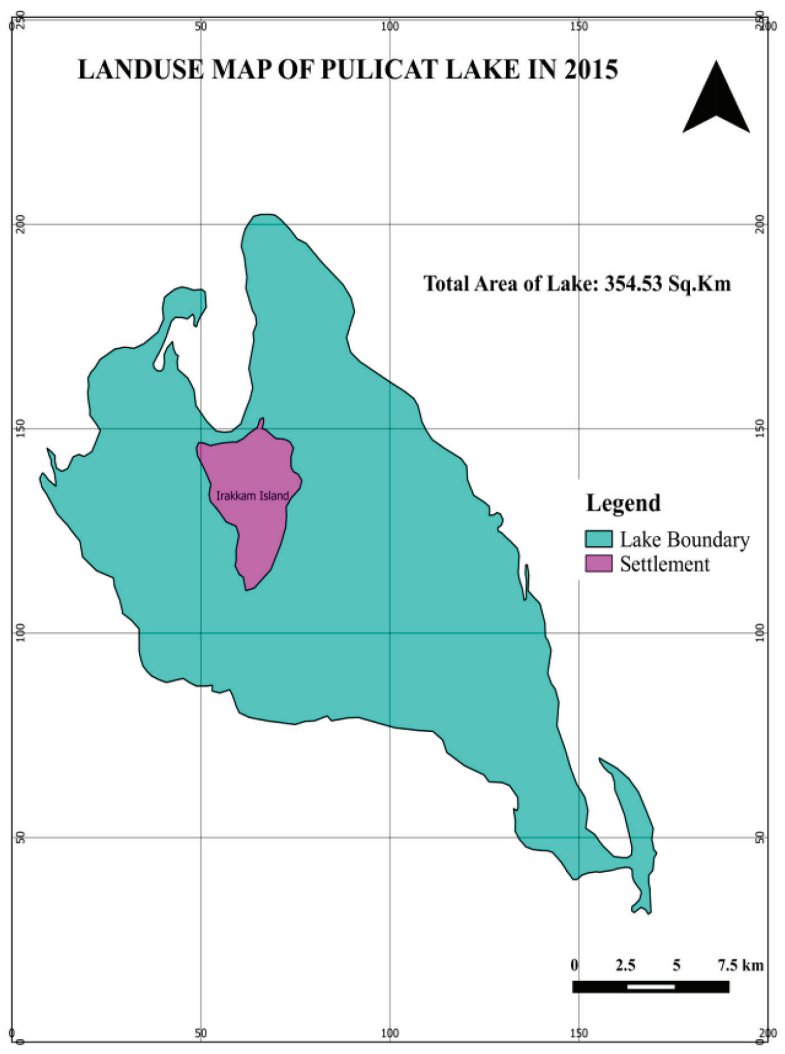

Fig. 5: Land use Map of Pulicat Lake in 2015 


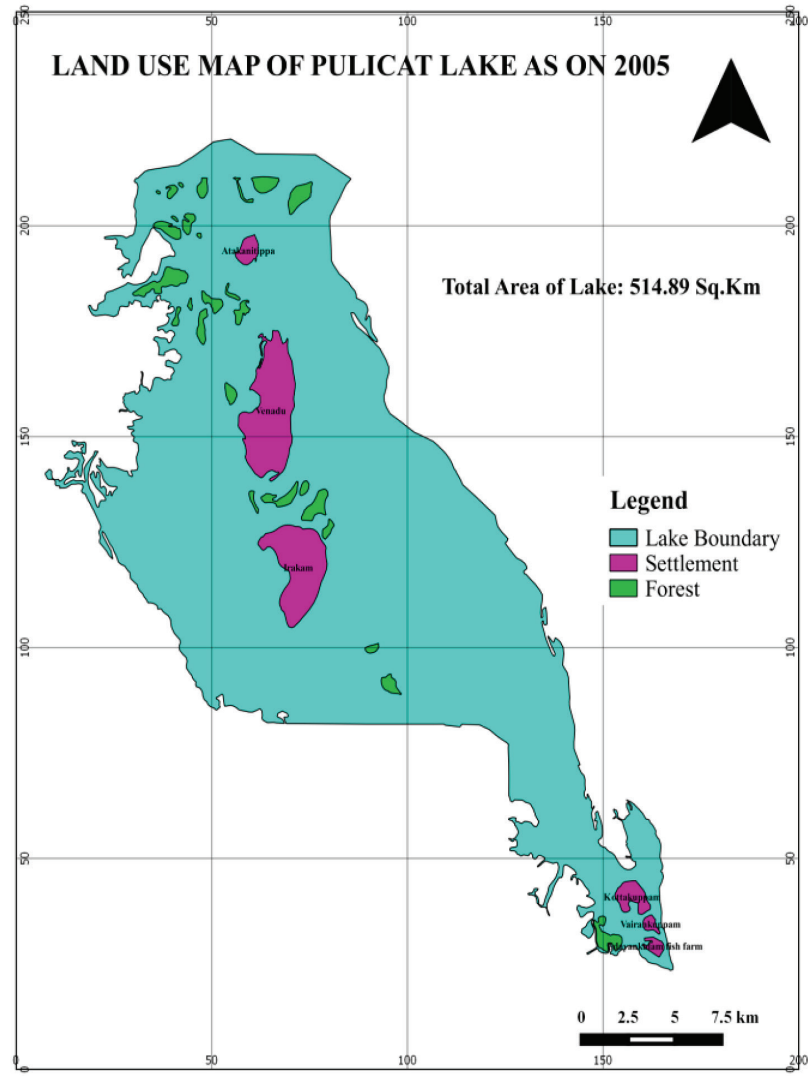

Fig. 4: Land Use Map of Pulicat lake in 2005

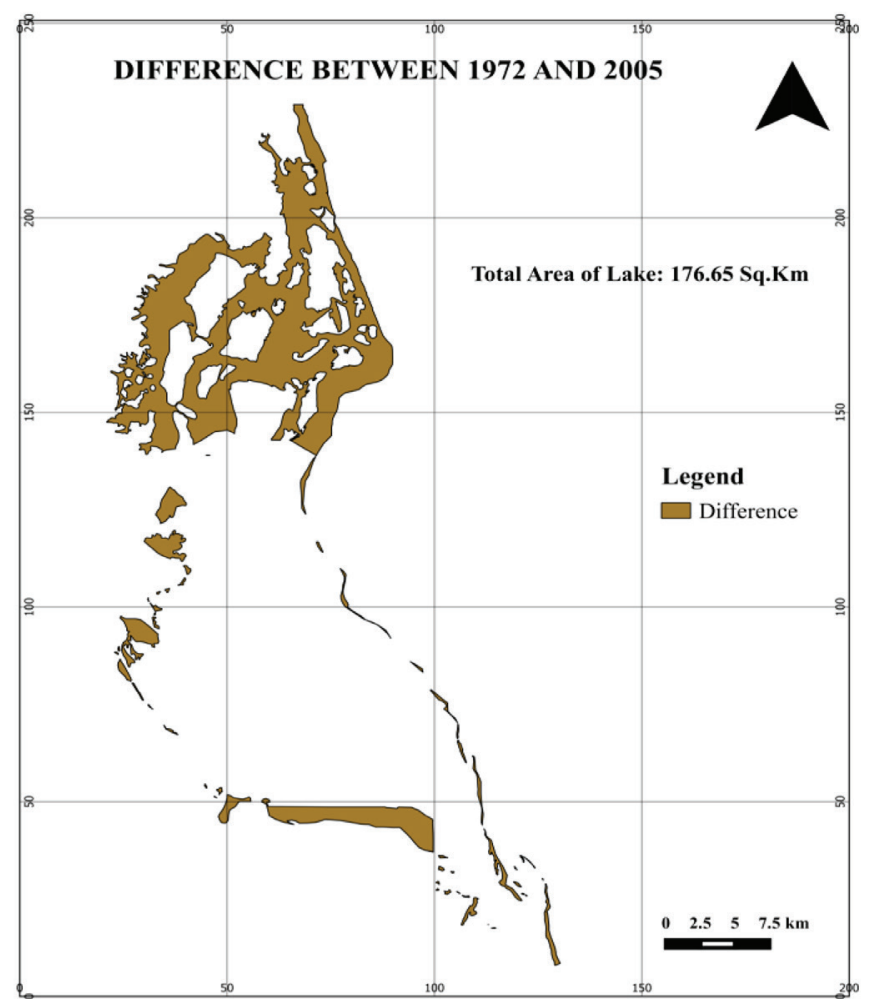

Fig. 6: Map showing changes in Pulicat lake between 1972 and 2005

\section{DIFFERENCE BETWEEN 1972 AND 2015}

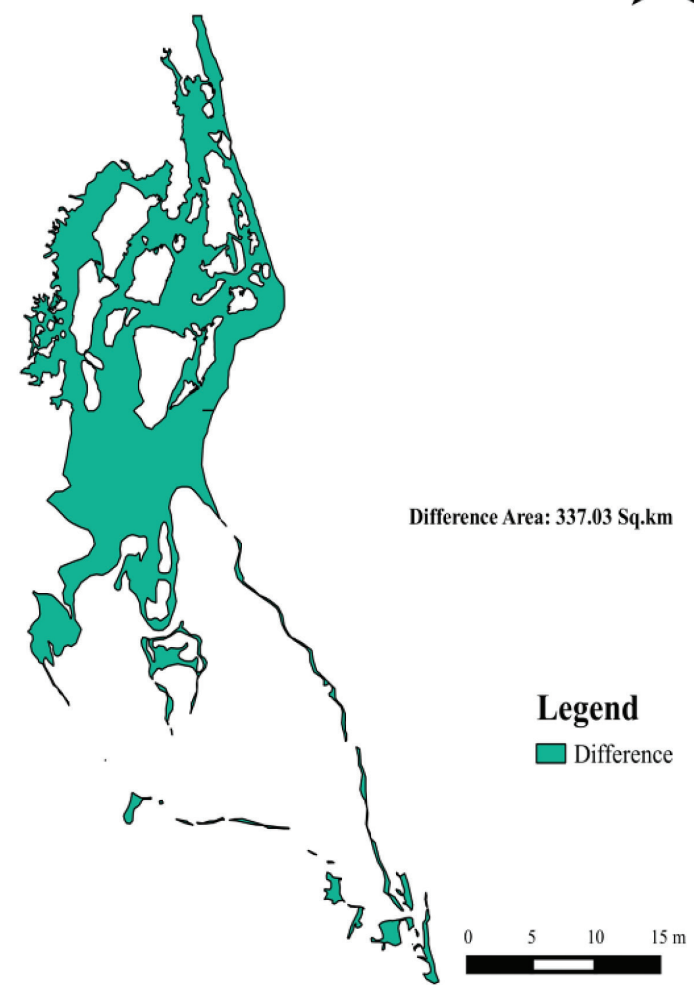

Fig. 7: Map showing changes in Pulicat Lake between 1972 and 2015

of the lake near Venadu showed medium sand. The centre of the lake showed silt and clay along with sand. The results of the sediment samples are shown in Figure 8(a) and Figure8(b)

The grain size of the suspended sediment in the lake bed ranges from 0.012 to $0.65 \mathrm{~mm}$. The grain size near the lake mouth and Buckingham canal ranges from 0.18 to $0.54 \mathrm{~mm}$, which lies in the medium to coarse sand category. The grain size in northern part of the lake near Venadu, Irrakam and Arambakkam ranges from 0.08 to $0.65 \mathrm{~mm}$ which lies in clay, silt and sand categories. The grain size in the centre part of the lake ranges from 0.0012 to $0.23 \mathrm{~mm}$. Analysis of bed samples indicate the presence of medium sand along with clay and silt.

The clay and silt consists of fine particles which are closely packed and can retain the water. The sandy soils are generally loosely packed and cannot retain the water. The Pulicat Lake shows sedimentation over the years. The turbidity in the lake also increased over the years. This sediment deposits are mostly of sand, silt and clay.

There is no significant variation in the moisture contents of the samples for the post-monsoon and summer seasons as the water level during these seasons are comparatively high. Moreover, the duration and temperature variation between sampling for the post-monsoon and summer seasons is less when compared to summer and pre-monsoon seasons.After summer and before the monsoon starts, the level of water slightly decreases and thus shows a reduction of moisture content for the pre-monsoon season. 

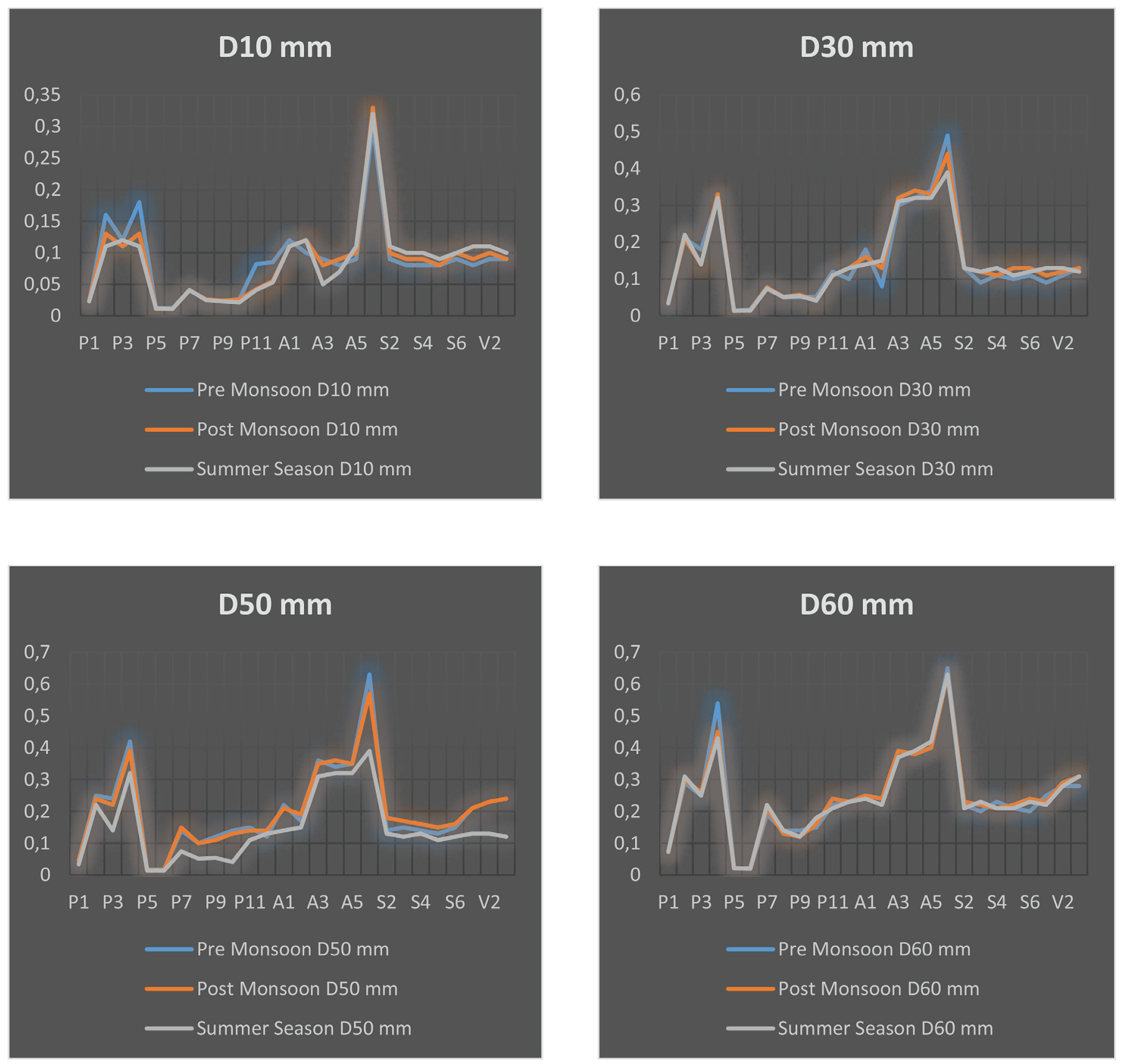

Fig. 8(a): Grain Size Distribution

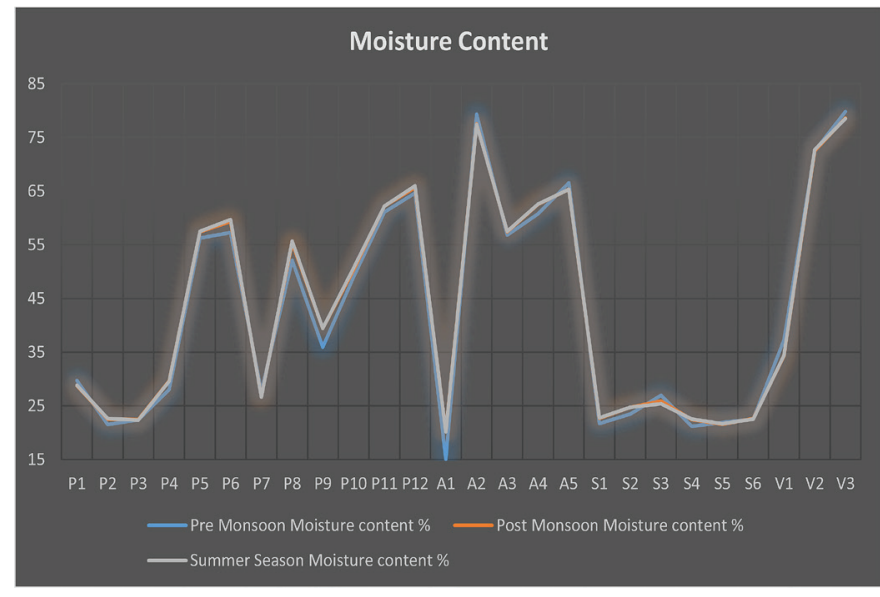

\subsection{Floral and Faunal Diversity}

\subsubsection{Aquatic fauna}

About eighty-one species of fishes, five species of prawns and three species of crabs are found in Pulicat Lake.The most dominant fish species are long-whiskered catfish (Mystus guli), river snapper (Lutjanus argentimaculatus), greenback mullet (Liza subviridus), flathead mullet (Mugil cephalus), Bloch's gizzard-shad (Nematalosanasus), Commerson's glassy perchlet (Ambasis commersoni), Mosambique tilapia (Oreochromis mossambica), Contaguri halfbeak (Hyporhamphus limbatus), spot-tail garfish (Strongylura strongylura) and milk fish (Chanos chanos)[15]. The commercial tiger shrimp and banana shrimp are dominant in Pulicat Lake. Turtles are found throughout the year in the lake.

Twelve species of amphibians found in the Pulicat Lake area, of

Fig. 8(b): Moisture Content. which the most common species were the ornate mocrohylid frog 
(Mycrohyla ornate), Indian cricket frog (Fejervarya limnocharis), painted kaloula (Kaloula taprobanica), Indian burrowing frog (Tomopterna rolandae), common Indian toad (Bufo melanostictus), Indian pond frog (Euphlyctis hexadactlyus) and skittering frog were recorded at Pulicat Lake[15]

\subsubsection{Avian Fauna}

Pulicat Lake attracts $80-100$ water birds belonging to 80 species every winter, some from Ladakh, Tibet and China [4]. It is significant that the near-threatened species like the spot-billed pelican, painted stork and the white ibis breed in the vicinity of the Pulicat Lake[9]. About 15,000 greater flamingoes spend the winter on the lake.

During the monsoon period, lake is filled by nutrient water and large numbers of both phytoplankton and zooplankton constitute essential food for invertebrates and fishes. The large amount of food attracts numerous wetland birds especially greater flamingoes along with pelicans, kingfisher, herons, painted storks, spoon bills, ducks, black drongoes, blue jays, common teals, coots, Cormorant littles, curlews, dabchicks, large egrets, little ergets, garganeys, little stints, open-billed storks, painted storks, pond herons, sand pipers, shovellers, white ibises, herring gulls etc. The concentration of flamingoes depends on the water level along with high algal, fish and benthic diversity. Kudiri, Moolah Kuppam, Annamalcheri are three important places where large number of flamingoes can be seen. The oriental white-backed vulture is a critically endangered species and the Spot- billed Pelican and Greater Spotted Eagle are vulnerable species of Pulicat Lake[4].

In the view of rich avian fauna of the lagoon, two bird sanctuaries were established in the lagoon, one in each of the two states of Andhra Pradesh and Tamil Nadu. The Andhra Pradesh portion of Pulicat Lake bird sacnctuary has an area of $172 \mathrm{sq} . \mathrm{km}$ in the Tada Taluk of Nellore District. The Tamil Nadu portion of the bird sanctuary has an area of $60 \mathrm{sq}$. km extending over the Ponneri and Gummidipundu Taluks of Tiruvallur District.

The checklist of birds prepared by the Wild Life Division of Andhra Pradesh listed 115 species of both aquatic and terrestrial Birds in the Pulicat Bird Sanctuary. More than 60,000 migrant water birds feed and breed in the northern part of lagoon during winter.

The birds seen in Pulicat Lake were classified under

- Breeding migrants

- Wintering aquatic migrants

- Wintering terrestrial migrants

- Resident aquatic migrants

- Resident terrestrial migrants

- Rare winter visitors

\subsubsection{Flora of the Lake}

The Pulicat Lake has several islands of which the larger islands are the Sriharikota Island, Venadu Island, Irrakam Island and Peranadu Island. The island have a very significant forest type called as Southern Tropical Dry Evergreen Forrest (TDEF).

Fifty-nine species of vegetation were recorded which includes 8 Cyanophyceae, 7 Chlorophyceae and 2 Rhodophyceae. Patches of dry evergreen forest and large areas of littoral scrub in fishing villages bordering the lagoon were also seen. The palm tree linings were found near the shores of the lake. Aquatic flora of the lake existed in two forms, namely microphytes and macrophytes which helps to maintain biodiversity of the lake [4]

Mangroves were found near Kallur village, Chinamangalu village, Kuruvitthitu Island, Arambakum village, Varagali village Four species of mangroves belonging to four families are prominent here. They include Aegiceras corniculatus of Myrsiraceae, Avicennia ma- rina of Aviceiniaceae, Excoecaria agallocha of Euphorbiaceae and Lumintzera racemosa of Combretaceae. At present mangrove plants of Avicinia species are very sparsely distributed in Pulicat Lake. They develop pneumatophores in response to oxygen deficient conditions. They are buffers between the land and the sea, and help in removing pollution, coastal erosion and protection from saline water intrusion and storms. These mangrove roots increase the nitrogen in water which is helpful for breeding of the aquatic organisms.

\subsection{Socio-Economic Survey}

The term socio economic refers to "indicators which pertain to the human-dimensions side of marine resource management[5]; relates to the distribution of benefits and income, livelihoods and local culture, and social organization and local culture".

\subsubsection{Findings}

- $94 \%$ of the respondents were male and $6 \%$ of the respondents were female

- $47 \%$ of the respondents completed primary education

- $76.7 \%$ of the respondents were married

- $9.3 \%$ of the respondents' income level were greater than Rs. 15,000

- $36.7 \%$ of the respondent's family size were 2 to 3 members

- $77 \%$ of the respondents used mechanized boats

- $62 \%$ of the respondents had cash savings

- $72.7 \%$ of the respondents did not have bank savings

- $74.3 \%$ of the respondents had invested their money in the chits

- $41 \%$ of the respondents invested 0 to 10,000 INR (Indian currency) for fishing nets

- $43 \%$ of the respondents invested 10,000 to 20,000 INR for boat hiring

- $54.3 \%$ of the respondents invested 0 to 10,000 INR for boat maintenance

- $42 \%$ of the respondents invested 10,000 to 20,000 INR for fuel expenses

- $40.7 \%$ of the respondents invested 10,000 to 20,000 INR for labors

- $39.7 \%$ of the respondents invested 0 to 10,000 INR for other fishing methods

- $43 \%$ of the respondents earned profit around 2,000 to 5,000 INR through own boating

- $57.7 \%$ of the respondents earned profit around 5,000 to 10,000 INR through leased boat

- $43.7 \%$ of the respondents earned profit around 2,000 to 5,000 INR through labors

- $54 \%$ of the respondents' income was around 5,000 to 10,000 INR through agriculture

- $52.7 \%$ of the respondents spent around 0 to 3,000 INR for food

- $49 \%$ of the respondents spent around 3,000 to 6,000 INR for fuel expenses

- $44.75 \%$ of the respondents spent 3,000 to 6,000 INR for medical expenses in a month

- $26.7 \%$ of the respondents were not clear about getting a support from government officials regarding fishing methods

- $28.3 \%$ of the respondents got good support from government officials regarding market price

- $33 \%$ of the respondents got good support from government officials regarding weather report

- $34.3 \%$ of the respondents got good support from government officials regarding safety measures 
- $34.3 \%$ of the respondents did not get support from government officials regarding natural disaster

- $26 \%$ of the respondents got a little support from government officials regarding promotion of handicrafts products

- $24.3 \%$ of the respondents got good support from government officials regarding vocational courses

\section{CONCLUSION AND RECOMMENDATIONS}

\subsection{Conclusion}

Satellite remote sensing and GIS study shows the major changes in the shore areas of the Pulicat Lake i.e. increase in settlements, industries and cropland and decrease in forest and water spread in the lake. The lake has been decreasing rapidly not only in its size and also in depth.

The siltation in Pulicat Lake and sand bar formation at the mouth of the lagoon threatens the complete ecological balance of the area. It is said that sediment size is more important than sediment type in influencing faunal distribution. Grain size and organic matter are also responsible for the population and production. Sediment size could be a controlling factor in the distribution of certain foraminifera in the lake.

Protection of biodiversity is urgently needd in order to maintain the balance of nature and support the availability of natural resources for future generations.

The islands of Pulicat Lake have remnants of Tropical Dry Evergreen Forest.. Mangrove reserves were found to be degraded over the years and their protection of lagoon and shoreline has declined. Casuarina and cashew plantations are more suitable for shoreline shield not only because they grow faster but they are also economical for local community[17].

\subsection{Recommendations}

- Good rules should be properly implemented to protect the construction and relevant activities near the lake

- Silt should be removed periodically, but without the loss of molluscans and lake submerged weeds. The submerged weeds are habitats for micro-fauna and rejuvenators of the oxygen level in lake area, as well as and food for a variety of aquatic organisms

- Groynes, stone wall, heaps of stones or tidal inlet walls should be constructed to prevent closure of sea mouth, followed by sand removal for the sustainable brackish water regime necessary for survival of migratory birds, aquatic fauna and lives of fisherman.

- Mitigation measures should be carried out by constructing parallel jetties on both sides of the inlets of Ennore Creek and Pulicat Lake to keep the inlet alive.

- Earthen road between Sullurpet and Sriharikota Island should be converted into a concrete bridge with vast space for free flow of water instead of cement pipes along $9.5 \mathrm{~km}$ length to prevent quick drying in the southern half of shallow water regimen.

- The silt should be detached from catchment areas of Swarnamukhi, and from other rivers that deposit silt into the lagoon. The siltation of lagoon has caused the reduction of its original depth and consequently affected its ecology.

- Silt yield reduction should be implemented in the catchment area by taking measures for various soil and water conserva- tion, in order to regulate the drainage outlets from the agricultural areas around the lagoon. This includes their treatment and periodical dredging of the silted up areas.

- Strict measures should be taken not to disturb natural dune and beach deposits

- Maintenance and enhancement of the diversity and distinctive nature of flora and fauna population in Pulicat sanctuary should be done.

- Studies should be done on the habits and needs of the winter visitors especially flamingoes, pintails, garganeys, Caspian terns, avocets and other species so as to provide them the suitable habitats.

- Maintenance of shallow water regime should be done near Rayadoruvu, Attakanithippa and Venadu with optimum salinity of brackish water regime during monsoon and also during the post-monsoon period up to April.

- Water storing pits of $100 \times 100$ feet with 1.5 feet depth should be installed near Attakanithippa on either side of $9.5 \mathrm{~km}$ road bridge where a few fishes survive during the post-monsoon period (January to April ) to act as food for painted storks and pelicans.

- The status of forests and favorable conditions for the main occupation of the people especially for fishing and agriculture should be monitored.

- The periodical phenomenon of birds in relation to weather conditions should be examined.

- Mangroves should be planted at the littoral area of the islands and sand bar edges instead of Casuarina, to provide nutrition to aquatic fauna as it acts as food for plankton which in turn act as food for fishes, shrimps in food chains.

- Mangroves should be planted on the islands at the littoral region of lake.

- Aquaculture farm effluent release into Buckingham canal which ultimately reaches Pulicat lake in Nellore district should be restricted.

- Impart awareness of responsible fishing should be taught.

- Promotion of ecotourism should be done to benefit the local community.

\section{APPENDIX}

\section{Questionnaire Form}

1. Gender - male/female

2. Village

3. Education - illiterate /primary/highersecondary/ug

4. Marital status - married/single

5. Income-<5,000, 5-10,000, 10-15,000, $>15,000$

6. Religion $-\mathrm{sc} / \mathrm{st} / \mathrm{obc} /$ others

7. Family; joint, nuclear,extended

8. Size of family - 1-2 $\quad 2-3 \quad 3-5 \quad 5-7$

9. Type of house lived
a. Kutcha or Pucca
b. Building
c. Mudhouse

10. Ownership of house Yes No 
11. Durables at home

\begin{tabular}{|c|l|c|c|}
\hline S.No & Name & YES & No \\
\hline 1 & Television & & \\
\hline 2 & Radio & & \\
\hline 3 & Mixer/Grinder & & \\
\hline 4 & Bicycle & & \\
\hline 5 & Two-wheeler & & \\
\hline 6 & Furniture & & \\
\hline 7 & Fan & & \\
\hline 8 & Gas & & \\
\hline
\end{tabular}

\section{Savings}

\begin{tabular}{|c|l|c|c|}
\hline S.No & Name & YES & No \\
\hline 1 & Cash savings & & \\
\hline 2 & Cooperative account savings & & \\
\hline 3 & Chits & & \\
\hline 4 & Jewellery & & \\
\hline
\end{tabular}

13. What type of machinery you adopt for fishing

\begin{tabular}{|c|l|c|}
\hline S.No & Name & YES \\
\hline 1 & Mechanised boat & \\
\hline 2 & Non mechanised boat & \\
\hline 3 & Catamaran & \\
\hline 4 & Others & \\
\hline
\end{tabular}

14. Annual investment made for fishing

\begin{tabular}{|c|l|c|c|c|c|}
\hline S.No & Name & $0-10 \mathrm{k}$ & $10-20 \mathrm{k}$ & $20-30 \mathrm{k}$ & $>30 \mathrm{k}$ \\
\hline 1 & Fishing nets & & & & \\
\hline 2 & Boat hiring & & & & \\
\hline 3 & Boat maintenance & & & & \\
\hline 4 & Fuel & & & & \\
\hline 5 & Labours & & & & \\
\hline 6 & Others & & & & \\
\hline
\end{tabular}

15. Mode of income for month

\begin{tabular}{|c|l|c|c|c|c|}
\hline S.No & Name & $2-5 \mathrm{k}$ & $5-10 \mathrm{k}$ & $10-15 \mathrm{k}$ & $>15 \mathrm{k}$ \\
\hline 1 & Own-boat fishing & & & & \\
\hline 2 & Leased boat & & & & \\
\hline 3 & Labourer & & & & \\
\hline 4 & Agriculture & & & & \\
\hline 5 & Other employment & & & & \\
\hline
\end{tabular}

16. Expenses for a month

\begin{tabular}{|c|l|c|c|c|c|}
\hline S.No & Name & $0-3 \mathrm{k}$ & $3-6 \mathrm{k}$ & $6-9 \mathrm{k}$ & $>9 \mathrm{k}$ \\
\hline 1 & Food & & & & \\
\hline 2 & Fuel & & & & \\
\hline 3 & Education & & & & \\
\hline 4 & Medical & & & & \\
\hline 5 & Clothing & & & & \\
\hline 6 & Entertainment & & & & \\
\hline
\end{tabular}

17. Quantity of fish caught in a day

\begin{tabular}{|l|l|l|l|}
\hline Season & Fish 1 & Fish 2 & Fish 3 \\
\hline Pre-monsoon & & & \\
\hline Post-monsoon & & & \\
\hline Summer & & & \\
\hline
\end{tabular}

18. Price for the fish

\begin{tabular}{|c|c|c|c|c|c|}
\hline Name of the fish & $\begin{array}{c}<100 \\
\text { per } \mathrm{kg}\end{array}$ & $\begin{array}{c}100-220 \\
/ \mathrm{kg}\end{array}$ & $\begin{array}{c}200-300 \\
/ \mathrm{kg}\end{array}$ & $\begin{array}{c}300-500 \\
/ \mathrm{kg}\end{array}$ & $>500 / \mathrm{kg}$ \\
\hline & & & & & \\
\hline
\end{tabular}

\section{Support Received From Government officials}

\begin{tabular}{|c|c|c|c|c|c|c|}
\hline S.No & Support from government officials & $\begin{array}{l}\frac{7}{.00} \\
\vec{z} \\
\vec{D} \\
\vec{D}\end{array}$ & 哥 & $\begin{array}{l}\bar{\pi} \\
\text { E्ञ } \\
\text { Z }\end{array}$ & $\underset{\stackrel{0}{\Xi}}{\stackrel{\Xi}{\Xi}}$ & $\begin{array}{l}\dot{\bar{D}} \\
\stackrel{\partial}{\Xi}\end{array}$ \\
\hline 1 & Fishing methods & & & & & \\
\hline 2 & Market price details & & & & & \\
\hline 3 & Weather reports & & & & & \\
\hline 4 & Training on safety measures & & & & & \\
\hline 5 & Natural disaster protection & & & & & \\
\hline 6 & Training in handicrafts & & & & & \\
\hline 7 & Training for vocational courses & & & & & \\
\hline
\end{tabular}

\section{Support received from other bodies}

\begin{tabular}{|c|c|c|c|c|c|c|}
\hline S.No & Support from Other Bodies & $\begin{array}{l}\frac{\overrightarrow{0}}{30} \\
\frac{00}{3} \\
\overrightarrow{0}\end{array}$ & 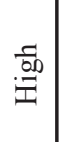 & $\begin{array}{l}\bar{\pi} \\
\stackrel{\Xi}{0} \\
\overline{0}\end{array}$ & $\stackrel{\stackrel{\mathscr{E}}{\Xi}}{\stackrel{\Xi}{ \pm}}$ & 芦 \\
\hline 1 & NGO & & & & & \\
\hline 2 & Cooperative banks & & & & & \\
\hline 3 & SHG & & & & & \\
\hline 4 & Volunteering organisation & & & & & \\
\hline
\end{tabular}

21. Health problems faced

\begin{tabular}{|c|c|c|c|c|c|c|}
\hline S.No & Physical Health Problems & $\begin{array}{l}\frac{0}{00} \\
\frac{3}{3} \\
\overrightarrow{0}\end{array}$ & $\begin{array}{l}\text { 해 } \\
.00\end{array}$ & $\begin{array}{l}\bar{T} \\
\overline{0} \\
\bar{Z}\end{array}$ & 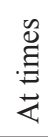 & $\begin{array}{l}\overline{0} \\
\dot{d} \\
\end{array}$ \\
\hline 1 & Fever & & & & & \\
\hline 2 & Jaundice & & & & & \\
\hline 3 & Back pain & & & & & \\
\hline 4 & Others & & & & & \\
\hline
\end{tabular}

22. Reason for poor health

\begin{tabular}{|c|l|l|l|l|l|l|}
\hline S.No & Reason & & & & & \\
\hline 1 & Lack of hospital & & & & & \\
\hline 2 & No transport & & & & & \\
\hline 3 & Environment & & & & & \\
\hline 4 & No local doctors & & & & & \\
\hline
\end{tabular}




\section{Acknowledgement}

Authors are thankful to PADI FOUNDATION, California for financial assistance provided under U.S. Common Grant Program to carryout this research study. Authors also place on record their gratitude to Dr.Priyadarshini and her team for the help rendered in designing the questionnaire and conducting the survey for socio-economic study. Authors also thank Mr.Jayanth Thangaraj, post graduate student for his help during sample collections.

\section{REFERENCES}

Kannan, V. - Manakadan, R. - P. Rao - Mohapatra, K. K. - Sivakumar, S. - Santharam, V. (2008) "The Waterbirds of Pulicat Lake, Andra Pradesh-Tamil Nadu,India,including those of the adjoining wetlands and heronries," J. Bombay Nat. Hist. Soc., vol. 105 , no. 2 , pp. $162-180$.

Ramesh, R. - Purvaja, R. - Ramesh, S. - James, R. A. (2002) "Historical pollution trends in coastal environments of india," Environ. Monit. Assess., vol. 79, no. 2, pp. 151-176.

Bhushan, S. - Rajashekhar (2001) "Pulicat lake, Nellore," Case studies-Tamilnadu, 1980. [Online]. Available: http://kalpavriksh. org/images/CCA/Directory/TN_CaseStudy-PulicatlskeNellore. pdf. [Accessed: 30-Nov-2015].

Basha, S. K. M. - Laksmi, E. R. - Rao, B. R. - Murthy, C. V. N. - Savithramma, N. (2012) "Biodiversity and Conservation of Pulicat Lake - Andhra Pradesh," Int. J. Geol., vol. 2, no. 2, pp. 129-135, 2012.

Thirunavukkarasu, N. - Goulakrishnan, S. - Premjothi, P. V. Moses Inbaraj, R. (2011) "Need of coastal resource management in Pulicat Lake - challenges ahead," Indian J. Sci. Technol., vol. 4, no. 3, 2011.

"Pulicat Lake facing ecological crisis," The Hind $u$, Chennai, 04-Jun2010.

Garg, J. K. (2015) - "Wetland assessment, monitoring and management in India using geospatial techniques, ” J. Environ. Manage., vol. 148, pp. 112-123, 2015.

Kannan, V. (2013) "Diminishing of Mangrove Cover Posing Potential Threats to the Biodiversity of Pulicat Lake, South India," Glob. J. Environ. Res., vol. 7, no. 3, pp. 52-55, 2013.

Krishna, N. C. - Raj, P. J. S. (2011) "Management of the food web in Pulicat Lake," INDIAN J. Environ. Educ., vol. 11, no. APRIL, pp. 1-52, 2011.
Pandian P. K. - Ramanamurthy M. V - Ramachandran, S. (2006) "Morphodynamics of the Tidal Inlets of Ennore Creek and Pulicat Lake, North Chennai Coast, Southeast India," J. Coast. esearch, vol. 2004, no. 39, pp. 2004-2007, 2006.

Mageshkumar, S. J. M. R, A. R. S - K. A. N. N. Model, "Modelling of Chlorophyll-A Concentrations in Pulicat Lagoon, Southeast Coast of India Using Artificial Neural Network," no. 2277, pp. 3-7, 2013.

Cook C. G. - Leng, M. J. - Jones, R. T. - Langdon, P. G. Zhang, E. (2012) "Lake ecosystem dynamics and links to climate change inferred from a stable isotope and organic palaeorecord from a mountain lake in southwestern," Quat. Res., vol. 77, no. 1, pp. 132-137, 2012.

BIS (1997) "IS 2720 Methods of Test for Soils:Determination of Water Content," vol. 2720, no. July 1973, 1997.

BIS (1985) "IS 2720 Methods of Test for Soils:Part 4 Grain Size Analysis," vol. 2720, pp. 1-38, 1985.

Kannan, V. (2015) "Battlefield through Bird Sanctuary- the Pulicat Lake,” 2010. [Online]. Available: http://www.globalnature.org/ bausteine.net/f/7442/pulictaLake-ReportKannan.pdf?fd=0. [Accessed: 30-Nov-2015].

Kannan, V. - Pandiyan, J. (2012) "Shorebirds (Charadriidae) of Pulicat Lake , India with Special Reference to Conservation," World J. Zool., vol. 7, no. 3, pp. 178-191, 2012.

Reddy, K. M. - Rao, A. N. - Bhagavan, S. V. B. K. (2010) "Integrated Study and addressing orf various measures for environmental problems of Pulicat Lagoon and ist catchment, parts of Andhra Pradesh and Tamilnadu, India," Grazer Schriften der Geogr. und Raumforsch., pp. 133-142, 2010. 